\title{
PENINGKATAN NILAI TAMBAH DAN SISTEM PENGOLAHAN PANGAN PASKA PANEN JAMUR TIRAM PUTIH DI SENTRA JAMUR PONDOK PESANTREN DARUSSALAM, NATAR
}

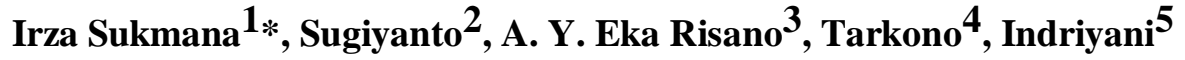 \\ 1), 2), 3),4) Jurusan Teknik Mesin, Fakultas Teknik Universitas Lampung \\ ${ }^{5)}$ Prodi Teknik Mesin, Fakultas Teknik, Universitas Sang Bumi Ruwai \\ irza.sukmana@gmail.com
}

\begin{abstract}
Abstrak
Pondok Pesantren Darussalam, Natar di Kabupaten Lampung Selatan merupakan salah satu sentra penghasil jamur tiram putih. Sentra jamur di pondok pesantren tersebut bertujuan untuk menjadi salah satu sumber pemasukan guru Yayasan dan juga dapat menjadi sarana belajar langsung bagi para siswa. Kegiatan Pengabdian kepada Masyarakat ini bertujuan untuk memberikan sosialisasi dan bimbingan teknis untuk peningkatan nilai tambah hasil budi daya jamur tiram putih yang berfokus pada implementasi mesin pengering spinner untuk hasil panen jamur. Selalin itu juga bertujuan untuk menjelakan berbagai teknik penyimpanan dan pengawetan hasil panen jamur tiram agar dapat memiliki umur yang lebih panjang. Teknologi pendukung produk paska panen jamur yang diimplementasikan adalah berupa alat pengering spinner (alat pengering putar). Berdasarkan hasil kuesioner dan bimbinban teknis yang telah dilaksanakan, secara umum peningkatan dalam aspek pemahaman peserta berkenaan teknik pengawetan jamur paska panen dan juga pemahaman dan kemampuan peserta dalam pengoperasian ipteks mesin pengering spinner bagi jamur tiram putih sebesar lebih dari 2 (dua) kali lipat atau $200 \%$, dimana dari rerata nilai pre-test 35,72 menjadi 87,30 .
\end{abstract}

Kata kunci :jamur tiram putih, mesin pengering, paska panen, pengawetan

\begin{abstract}
Pondok Pesantren Darussalam, Natar city in South Lampung District is one of the centers for producing white oyster mushrooms. The mushroom center in this boarding school aims to be a source of income for the Foundation's teachers and also as a means of direct learning for students. This Community Service activity aims to provide socialization and technical guidance to increase the added value of white oyster mushroom cultivation that focuses on implementing spinner drying machines for mushroom harvesting. Also, it aims to describe various techniques for storing and preserving oyster mushroom crops in order to have a longer life. The technology to support post-harvest mushroom products that is implemented is in the form of a spinner dryer. Based on the results of the questionnaire and technical guidance that has been carried out, in general the increase in the aspects of the participants understanding regarding post-harvest mushroom preservation techniques and also the participants' understanding and ability in operating science and technology for spinner drying machines for white oyster mushrooms is more than 2 (two) times or 200. \%, where from the mean score of pre-test of 35.72 to the post-tests of 87.30 .
\end{abstract}

Keywords : jamur tiram putih, mesin pengering, paska panen, pengawetan

\section{PENDAHULUAN}

Pemerintah Indonesia terus berupaya meningkatkan minat masyarakat dalam mengkonsumsi berbagai hasil alam lokal yang memiliki nilai gizi yang tinggi, termasuk jamur. Selain memiliki nilai gizi yang tinggi, jamur juga memiliki berbagai kelebihan, seperti: kandungan kalori, vitamin, dan berbagai mineral yang bermanfaat bagi tubuh. Selain itu, jamur juga memiliki khasiat sebagai makanan yang berkhasiat sebagai obat karena 
mengandung zat anti oksidan dan rendah kolesterol. Jamur juga memiliki kandungan protein sekitar 20\% dari bobot keringnya [1].

Untuk meningkatkan nilai konsumsi jamur di Indonesia, berbagai usaha telah dilaksanakan, termasuk membangun berbagai komunitas dan kelompok usaha jamur, seperti: Masyarakat Agribisnis Jamur Indonesia (MAJI). MAJI melakukan edukasi kepada masyarakat dan rumah tangga untuk dapat mengembangkan budi daya jamur untuk konsumsi sendiri (rumah tangga) dan untuk dapat dijual sebagai usaha kecil rumah tangga [2]. Di Propinsi Lampung, berbagai usaha dan budidaya jamur juga telah digalakkan, termasuk di Pondok Pesantren Darussalam, Natar.

Jamur tiram putih atau sering disebut pleurotus osteatus merupakan jenis jamur yang sering tumbuh pada kayu yang lapuk. Jenis jamur ini ditandai dengan ciri-ciri jenis tudung yang membulat datar, melengkung seperti cangkang tiram dan tangkai buah di pinggir tudung. Oleh karena sifatnya yang mudah tumbuh pada kayu yang lapuk, maka dalam proses budi daya jamur tiram putih juga dimungkinkan dengan memberikan media tumbuh berbahan kayu.

Hal-hal yang menunjang budidaya jamur tiram harus diperhatikan sebelum melakukan penanaman. Persiapan matang membantu menciptakan suasana kondusif bagi pertumbuhan jamur tiram sehingga menunjang keberhasilan budidaya. Langkah-langkah yang harus dilakukan diantaranya membuat rumah kumbung baglog, rak baglog, menyediakan bibit, serta menyediakan peralatan budidaya media tanam jamur tiram secara umum terdiri dari serbuk gergaji $100 \mathrm{~kg}$; tepung jagung $10 \mathrm{~kg}$; dedak halus atau bekatul 10kg; kompos 0,5kg; kapur (CaCo3) 0,5kg; serta tambahan air hingga 50-60\% [2-3].

Sentra jamur di Pondok Pesantren Darussalam mengkhususkan diri pada budidaya jenis jamur tiram putih yang termasuk salah satu jenis jamur konsumsi yang diminati oleh sebagian besar masyarakat di Indonesia. Jamur tiram putih tercatat dikonsumsi oleh masyarakat sekitar $55-60 \%$ dari total produksi semua jenis jamur yang diproduksi di Indonesia [3-4]. Bagi masyarakat luas, jamur tiram putih telah menjadi preferensi (pilihan) masyarakat dibandingkan jamur jenis lain, diantaranya karena: memiliki rasa yang lezat, bergizi tinggi dan mengandug zat zat yang berkhasiat obat sehingga bermanfaat untuk menjaga kesehatan dan menyembuhkan penyakit tertentu.

Dari segi teknik budidaya, keunggulan jamur tiram adalah dapat tumbuh sepanjang tahun tanpa tergantung pada musim sehingga pemanenanya bisa dilakukan setiap hari, bahan baku untuk media penanaman jamur mudah diperoleh, pembudidayaannya tidak membutuhkan lahan yang luas, teknologi budi daya yang mudah diterapkan, resiko kegagalan yang rendah, dan termasuk jamur yang "kebal" terhadap serangan hama penyakit [5-6].

Keterbatasan jenis porduk paska panen dan keterbatasan masa konsumsi produk jamur sangat singkat. Hal tersebut, diantaranya dikarenakan kandungan air yang masih tinggi, sehingga berbagai produk paska panen jamur tidak dapat bertahan lama. Oleh karena itu, dalam pengabdian ini dilakukan penyuluhan mengenai berbagai jenis penganan dan produk paska panen jamur tiram putih serta transfer informasi mengenai teknologi pengering jamur yang berbasis teknik spinner (pemutar).

Sebagai salah satu pemangku teknologi produksi, Jurusan Teknik Mesin FT Unila, melalui proposal pengabdian kepada masyarakat ini, diharapkan adanya peningkatan 
pengetahuan para pengusaha jamur dan masyarakat luas akan pentingya jamur dan berbagai produk paska panennya. Serta pemahaman pentingnya implementasi mesin spinner (pengering) jamur yang berbasis rotasi sumbu putar agar dapat mengurangi kadar air hasil panen jamur sehingga dapat meningkatkan umur konsumsi berbagai olahan jamur tiram putih di Pesantren Darussalam, Desa Banjar Negeri, Kecamatan Natar Lampung Selatan.

\section{Waktu dan tempat}

Waktu Pelaksanaan

Tempat

\section{Penyelenggara}

Penyelenggara kegiatan ini adalah Staf Pengajar Jurusan Teknik Mesin dan Program Studi Teknik Informatika (lintas bidang) pada Fakultas Teknik - Universitas Lampung, dengan dibiayai dari dana DIPA Fakultas Teknik Universitas Lampung.

\section{Metode Kegiatan}

Metode kegiatan Pengabdian kepada Masyarakat yang digunakan ini terdiri dalam 2 (dua) macam kegiatan, sebagai berikut:

a. Ceramah

Kegiatan ceramah diperlukan untuk memberikan dasar pemahaman mengenai pentingnya jamur tiram, peluang usaha jamur tiram, cara pembudidayaan jamur tiram, dan berbagai potensi makanan olahan paska panen jamur tiram putih.

Dalam kegiatan ceramah ini dapat dibagi menjadi 3 (tiga) pembahasan utama, yaitu: (a) Dasar-dasar jamur tiram putih: nilai gizi, potensi usaha, dan cara budidaya jamur tiram putih; (b) Penanganan produk jamur tiram paska panen (termasuk cara melakukan panan jamur yang baik, metode penyimpanan jamur, cara pengeringan konvensional, dan berbagai produk paska panen jamur tiram putih); dan (c) Alat dan teknologi paska panen, yang dalam hal ini difokuskan pada pejelasan mengenai pentingnya implementasi alat pengering jamur metoda dry spinner (pengering putar). b. Konsultasi

Kegiatan konsultasi yang diberikan diantaranya adalah konsep disain dan aplikasi alat penering putar untuk produk jamur paska panen, dimana implementasi alat pengering jamur diharapkan dapat meningkatkan umur jamur paska panen, sehingga dapat meningkatkan nilai penjualan pengusaha jamur dan sekaligus meningkatkan potensi produksi berbagai makanan paska panen jamur tiram yang memiliki gizi dan protein tinggi.

Kegiatan konsultasi dalam pengabdian masyarakat ini banyak diisi persoalan teknis rencana produksi alat dan berbagai spesifikasi produk alat yang dapat diaplikasikan untuk sentra jamur di pondok pesantren Darussalam Natar.

\section{HASIL DAN PEMBAHASAN}

\section{Hasil Kegiatan Ceramah}

Kegiatan ceramah dilakukan dengan memberikan test awal (pre-test), kemudian materi presentasi kepada peserta pengabdian, tanya jawab, dan diakhiri dengan test akhri (post-test). Topik test dapat dibagi menjadi 3 (tiga) katagori, yaitu: pengetahuan umum mengenai jamur, pemahaman teknik paska panen jamur tiram putih dan berbagai jenis 
produk makanan yang dapat dibuat dari jamur putih, dan pemahaman tentang alat dan teknologi pengering jamur dengan system sumbu putar (spinner).

Ceramah dilakukan dengan memberikan presentasi selama lebih kurang 20 s.d. 30 menit dan diikuti dengan tanya jawab peserta mengenai materi presentasi yang sudah diberikan. Berdasarkan pengamatan dan data dukung selama pelaksanaan kegiatan, terlihat bahwa antusiasme masyarakat sangat baik. Terutama bagi peserta yang sudah melakukan usaha kecil pembudidayaan jamur tiram putih.

Selain pebudidaya dari ponpes Darussalam, juga terdapat pengusaha lain yang bergerak di bidang yang sama. Hasil nilai pengetahuan berdasarkan metoda pengabdian ceramah ditunjukkan sesuai hasil pre-test dan post-test PkM jamur tiram di pondok pesantren Darussalam Natar, sebagai mana Tabel 1.

\section{Tabel 1. Hasil Pre-Test Pengabdian Jamur Tiram Putih}

\begin{tabular}{|c|c|c|c|c|c|c|c|c|c|c|c|}
\hline \multirow[b]{2}{*}{$\mathbf{N}$} & \multirow[b]{2}{*}{ No. } & \multicolumn{9}{|c|}{$\mathbf{S}$} & \multirow{2}{*}{ 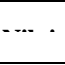 } \\
\hline & & 1 & 2 & 3 & 4 & 5 & 6 & 7 & 8 & Juml & \\
\hline 1 & Peserta 1 & 0 & 0 & 0 & 1 & 1 & 0 & 1 & 0 & 3 & 3 \\
\hline 2 & Peserta 2 & 1 & 0 & 0 & 0 & 0 & 0 & 1 & 1 & 3 & 3 \\
\hline 3 & Peserta 3 & 0 & 0 & 0 & 1 & 1 & 0 & 1 & 0 & 3 & 3 \\
\hline 4 & Peserta 4 & 0 & 0 & 0 & 0 & 0 & 1 & 1 & 0 & 2 & 2 \\
\hline 5 & Peserta 5 & 0 & 1 & 0 & 1 & 1 & 1 & 0 & 0 & 4 & 5 \\
\hline 6 & Peserta 6 & 0 & 1 & 0 & 1 & 0 & 0 & 0 & 0 & 2 & 2 \\
\hline 7 & Peserta 7 & 1 & 1 & 0 & 0 & 1 & 1 & 0 & 0 & 4 & 5 \\
\hline 8 & Peserta 8 & 1 & 1 & 0 & 0 & 1 & 0 & 0 & 0 & 3 & 3 \\
\hline 9 & Peserta 9 & 0 & 0 & 0 & 1 & 0 & 0 & 1 & 0 & 2 & 2 \\
\hline 1 & Peserta 10 & 0 & 1 & 0 & 0 & 0 & 0 & 1 & 1 & 3 & 3 \\
\hline 1 & Peserta 11 & 0 & 0 & 0 & 1 & 1 & 0 & 1 & 1 & 4 & 5 \\
\hline 1 & Peserta 12 & 0 & 0 & 0 & 0 & 0 & 0 & 1 & 0 & 1 & 1 \\
\hline 1 & Peserta 13 & 0 & 0 & 1 & 1 & 0 & 0 & 0 & 1 & 3 & 3 \\
\hline 1 & Peserta 14 & 0 & 0 & 1 & 1 & 0 & 0 & 0 & 0 & 2 & 2 \\
\hline & Total & 3 & 5 & 2 & 8 & 6 & 3 & 8 & 4 & 39 & \\
\hline
\end{tabular}

Selanjutnya, analisis hasil pre-test sesuai Tabel 1 di atas adalah sebagai berikut:

a. Peserta umumnya memiliki pemahaman yang tidak tinggi dalam ke-3 aspek pengabdian yang dipertanyakan di atas.

b. Angka tertinggi dari pre-test adalah $50 \%$ sebanyak 3 (tiga) orang, sementara 1 (satu) orang mendapatkan skor terendah dengan hanya mamapu menjawab 1 (satu) pertanyaan dengan benar.

c. Secara keseluruhan, peserta memiliki nilai pre-test rata-rata sebesar 34,82 atau di bawah $50 \%$. Hal ini menunjukkan kurangnya pemahaman peserta terhadap ke-3 aspek yang akan dianalisa di atas.

Soal post-test pengabdian diberikan setelah sesi presentasi dan tanya-jawab selama lebih kurang 30 s.d. 45 menit. Secara umum, hasil post-test menunjukkan peningkatan secara seragam terhadap ke-3 aspek tujuan PkM, sebagaimana Tabel 2

Tabel 2. Hasil Post-Test Pengabdian Jamur Tiram Putih

\begin{tabular}{llllllllllll}
\hline $\mathbf{N}$ & Pesert & 1 & 2 & 3 & 4 & 5 & 6 & 7 & 8 & Juml & Nilai \\
\hline $\mathbf{1}$ & Peserta 1 & 1 & 1 & 1 & 1 & 1 & 1 & 1 & 1 & 8 & $\mathbf{1}$ \\
\hline $\mathbf{2}$ & Peserta 2 & 0 & 1 & 1 & 1 & 0 & 1 & 1 & 1 & 6 & $\mathbf{7}$ \\
\hline $\mathbf{3}$ & Peserta 3 & 1 & 1 & 1 & 1 & 0 & 1 & 1 & 1 & 7 & $\mathbf{8}$ \\
\hline $\mathbf{4}$ & Peserta 4 & 0 & 1 & 0 & 1 & 1 & 1 & 1 & 1 & 6 & $\mathbf{7}$ \\
\hline $\mathbf{5}$ & Peserta 5 & 1 & 0 & 1 & 1 & 1 & 1 & 1 & 1 & 7 & $\mathbf{8}$ \\
\hline $\mathbf{6}$ & Peserta 6 & 1 & 1 & 1 & 1 & 1 & 1 & 1 & 1 & 8 & $\mathbf{1}$ \\
\hline $\mathbf{7}$ & Peserta 7 & 0 & 1 & 1 & 1 & 1 & 0 & 1 & 1 & 6 & $\mathbf{7}$ \\
\hline $\mathbf{8}$ & Peserta 8 & 1 & 1 & 0 & 1 & 0 & 1 & 1 & 1 & 6 & $\mathbf{7}$ \\
\hline $\mathbf{9}$ & Peserta 9 & 1 & 1 & 1 & 1 & 0 & 1 & 1 & 1 & 7 & $\mathbf{8}$
\end{tabular}




\begin{tabular}{rrrrrrrrrrrr}
\hline $\mathbf{1}$ & Peserta 10 & 1 & 1 & 1 & 1 & 0 & 1 & 1 & 1 & 7 & $\mathbf{8}$ \\
\hline $\mathbf{1}$ & Peserta 11 & 1 & 1 & 1 & 1 & 0 & 0 & 1 & 1 & 6 & $\mathbf{7}$ \\
\hline $\mathbf{1}$ & Peserta 12 & 1 & 1 & 1 & 1 & 1 & 1 & 1 & 1 & 8 & $\mathbf{1}$ \\
\hline $\mathbf{1}$ & Peserta 13 & 1 & 1 & 1 & 1 & 1 & 0 & 1 & 1 & 7 & $\mathbf{8}$ \\
\hline $\mathbf{1}$ & Peserta 14 & 1 & 1 & 1 & 1 & 1 & 0 & 1 & 1 & 7 & $\mathbf{8}$ \\
\hline & Total & $\mathbf{1 1}$ & $\mathbf{1 3}$ & $\mathbf{1 2}$ & $\mathbf{1 4}$ & $\mathbf{8}$ & $\mathbf{1 0}$ & $\mathbf{1 4}$ & $\mathbf{1 4}$ & $\mathbf{9 6}$ & 85
\end{tabular}

Berdasarkan data pada Tabel 2 di atas, berikut adalah analisis hasil post-test PkM:

a. Terdapat 3 (tiga) orang peserta yang mendapatkan poin maksimum atau mamapu menjawab semua pertanyaan dengan benar, sementara nilai terendah dari post-test adalah $75 \%$.

b. Secara umum terdapat peningkatan nilai di semua pertanyaan yang diberikan atau peningkatan pengetahuan pada keseluruhan 3 (tiga) aspek yang ditinjau dalam ceramah.

c. Perlu adanya telaah khusus untuk menganalisa peningkatan ke-3 aspek yang ditinjau dengan menggabungkan semua nilai yang mewakili masing-masing pertanyaan. Berikut adalah pembagian dari ke-3 aspek yang ditanyakan kepada peserta:

a. Aspek pengetahuan umum mengenai jamur dan budidaya jamur tiram putih, terdiri dari pertanyaan-pertanyaan berikut:

1. Jamur Tiram termasuk salah satu hasil alam Indonesia yang sangat digalakkan Pemerintah untuk peningkatan gizi masyarakat, dimana kandungan proteinnya diperkirakan.....
a. $10-20 \%$
b. $30-50 \%$
c. Tidak tahu/ragu-

ragu

2. Total produksi jamur tiram disbanding semua jenis jamur di Indonesia diperkirakan sekitar:.....
a. $20-30 \%$
b. $50-60 \%$
c. $70-80 \%$
d. Tidak tahu/ragu-ragu

3. Selain protein, jamur tiram putih juga memiliki kandungan lain yang penting untuk tubuh manusia, diantaranya sebagaimana di bawah ini:

a. Vitamin, fosfor, natrium, dan kalsium b. Karbohidrat, magnesium, timbal, mangan dan protein lain $\quad$ c. Vitamin, fosfor, kalsium, karbohidrat, timbal, mangan dan

protein $b$. Aspek pengetahuan produk dan olahan makanan paska panen serta umur jamur hasil panen, terdiri dari pertanyaan-pertanyaan berikut:

5. Konsep penanganan paska panen jamur tiram putih diantaranya terdiri dari beberapa prinsip di bawah ini, kecuali:

a. Perlunya penghambat laju respirasi selama penyimpanan dan pengiriman b. Perlunya sinar matahari yang banyak agar produk paska panen tetap segar c. Tidak tahu/Ragu-ragu

6. Menurut Bapak/Ibu berikut adalah beberapa cara pengawetan produk jamur paska panen secara alami/natural, kecuali:
a. Pengawetan segar
b. Penggaraman
c. Keduanya betul d. Keduanya salah

7. Selain proses pengawetan alami di atas, Apakah Bapak/Ibu mengetahui adanya metode pengeringan jamur dengan cara spinner?
a. Belum tahu / ragu-ragu
b. Tahu sedikit
c. Sangat tahu
c. Terakhir adalah pemahaman mengenai alat/mesin dan atau teknologi yang dapat diimplementasikan pada jamur hasil panen, dengan pertanyaan sebagai berikut:

4. Apakah Bapk/Ibu memahami cara budidaya dan teknologi pengolahan penganan/makanan paska panen jamur tiram putih?
a. Ya, Tahu sekali
b. Tahu Sebagian
c. Tahu sedikit/belum tahu
8. Apakah Bapak/Ibu memahami komponen utama alat spinner pengeringan jamur?
a. Belum tahu / ragu-ragu
b. Tahu sedikit
c. Sangat tahu

Berdasarkan hasil pre-test dan post-test tersebut, maka dapat dibuatkan evaluasi umumnya secara lengkap, sebagaimana Tabel 3. 
Tabel 3. Perbandingan Hasil Pre- dan Post-Test Pengabdian Jamur Tiram Putih

\begin{tabular}{|c|c|c|c|c|c|}
\hline Unsur Soal & $\begin{array}{c}\text { Juml } \\
\text { ah } \\
\text { Nilai } \\
\text { Pre- } \\
\text { - }\end{array}$ & $\begin{array}{c}\text { Rerata } \\
\text { Pre- } \\
\text { Test } \\
\text {... }\end{array}$ & $\begin{array}{c}\text { Jumla } \\
\text { h nilai } \\
\text { Post- } \\
\text { Test }\end{array}$ & $\begin{array}{c}\text { Rerata } \\
\text { Post- } \\
\text { Test } \\
\text { T... }\end{array}$ & $\begin{array}{l}\text { Peningk } \\
\text { atan } \\
\text { Nila } \\
\text { i }\end{array}$ \\
\hline $\begin{array}{l}\text { Pemahaman } \\
\text { Jamur } \\
\text { Tiram }\end{array}$ & 10 & $\begin{array}{l}2 \\
3,\end{array}$ & 36 & $\begin{array}{l}8 \\
5\end{array}$ & $\begin{array}{l}6 \\
1\end{array}$ \\
\hline $\begin{array}{l}\text { Pemahaman Alat } \\
\text { dan } \\
\text { Teknologi }\end{array}$ & 12 & $\begin{array}{l}4 \\
2,\end{array}$ & 28 & 100 & $\begin{array}{l}5 \\
7\end{array}$ \\
\hline $\begin{array}{l}\text { Pemahaman } \\
\text { Paska } \\
\text { Panen }\end{array}$ & 17 & $\begin{array}{l}4 \\
0,\end{array}$ & 32 & $\begin{array}{l}7 \\
6,\end{array}$ & $\begin{array}{l}3 \\
5\end{array}$ \\
\hline Nilai rerata & & $\begin{array}{l}35,7 \\
2\end{array}$ & & $\begin{array}{l}87,3 \\
0\end{array}$ & $\begin{array}{l}5 \\
1\end{array}$ \\
\hline
\end{tabular}

\section{Kegiatan Konsultasi}

Kegiatan konsultasi berisi proses tanya-jawab langsung dengan pengusaha budidaya jamur tiram putih untuk mendapatkan informasi mendasar yang dapat digunakan dalam proses perancangan alat/mesin pengering jamur. Konsultasi dilakukan beberapa kali selama masa kegiatan pengabdian atau dari bulan Juli s.d. 19

September 2020 atau hingga saat pelaksanaan kegiatan PkM. Data hasil diskusi dan konsultasi tersebut kemudian dituangkan dalam konsep disain alat pengering jamur tiram putih dengan metode spinner (poros putar). Konsep disain bagian utama alat pengering jamur spinner adalah sebagaimana Gambar 1 berikut ini.

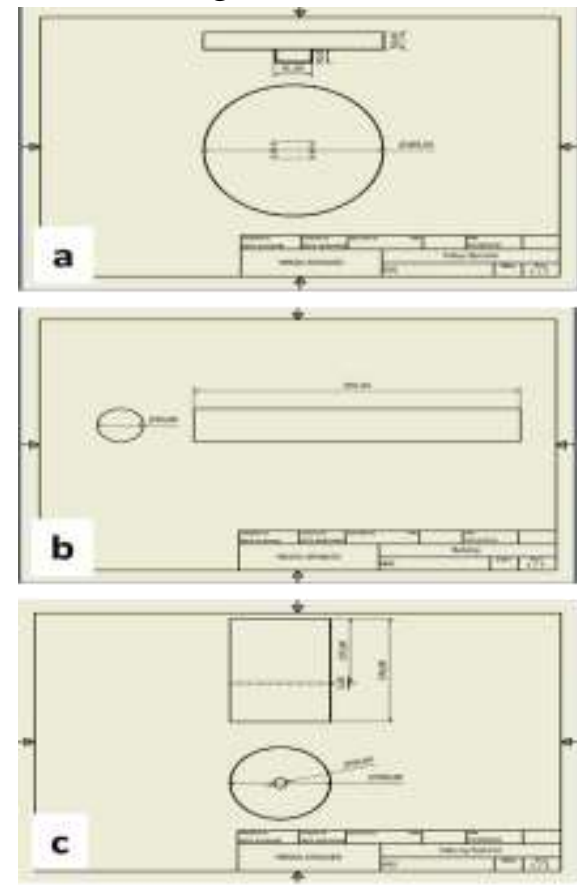

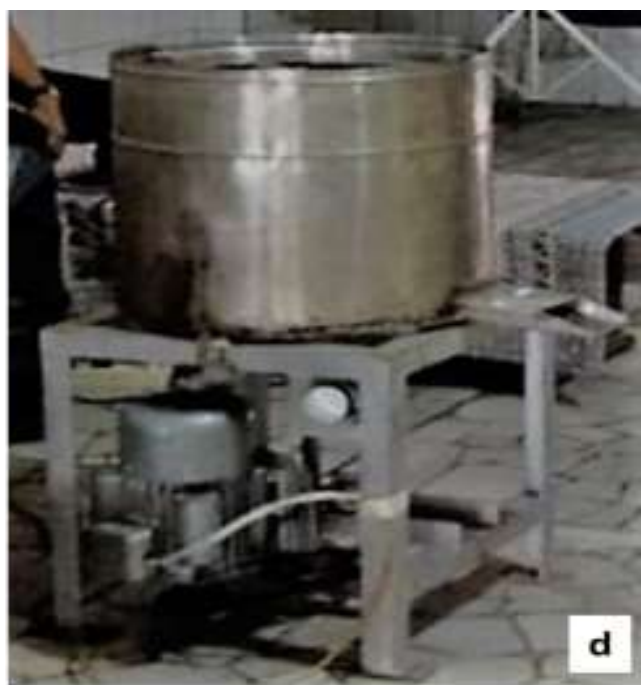

a) Alat spinner tampak atas

b) Poros pemutar utama

c) Tabung pengering spinner

d) Alat pengering spinner

Gambar 1. Alat pengering spinner lengkap 


\section{Dokumentasi Kegiatan PkM}

Dokumentasi kegiatan ceramah dan konsultasi yang telah dilaksanakan pada tanggal 19 September 2020 di Pd. Pesantren Darussalam, Kec. Natar adalah sebagaimana pada Gambar 2.
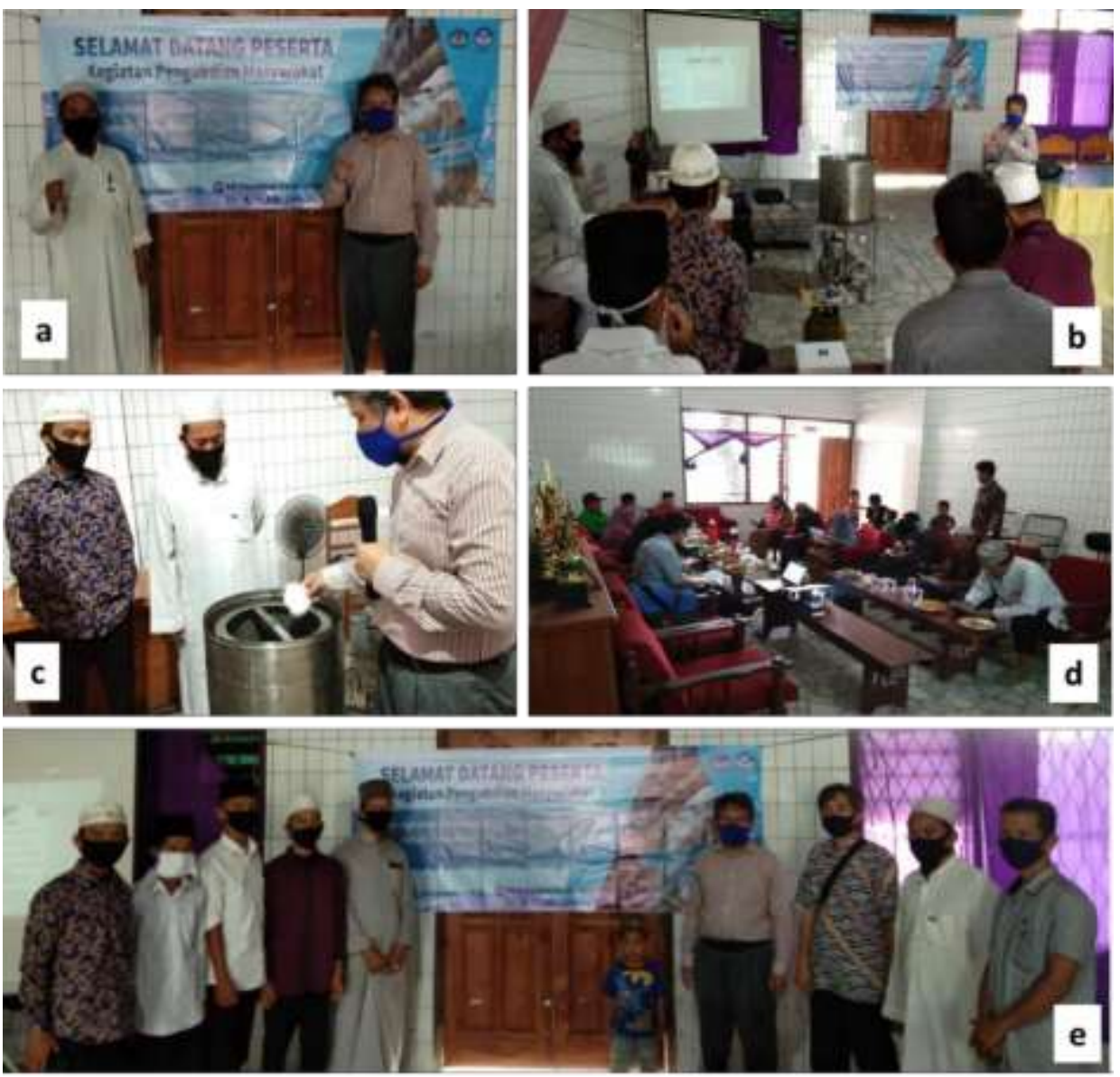

Gambar 2. Dokumentasi kegiatan PkM : (a) Ketua Panitia dan Pengelola Budidaya jamur (b) Sesi Ceramah (c) Sesi Praktek dan Konsultasi (d) Sesi Pre dan Post-test PkM, dan (e) Sesi foto Bersama peserta lelaki

\section{KESIMPULAN}

Berdasarkan data perbandingan antara hasil pre-test dan post-test menunjukkan secara keseluruhan bahwa kegiatan pengabdian kepada masyarakat ini dapat meningkatkan ke-3 aspek yang diharapkan, dimana peningkatan tertinggi adalah pada aspek pemahaman dan usaha jamur tiram putih sebesar $61,90 \%$, sementara untuk pemahaman alat dan teknologi paska panen $57,14 \%$ dan sistem pengelolaan paska panen $35,71 \%$ atau dengan rata-rata sebesar 51,58\%. Selain itu, pemahaman dan kemampuan peserta PkM mengenai alat pengering spinner maupun cara penggunaannya juga meningkat, mengingat peserta belum pernah melihat secara langsung alat pengering spinner yang telah dikonsultasikan selama proses perancangan dan disainnya 


\section{UCAPAN TERIMAKASIH}

Penulis mengucapkan terima kasih atas support finansial dari Lembaga Penelitian dan Pengabdian Masyarakat (LPPM) Universitas Lampung melalui Hibah Pengabdian Kepada Masyarakat - PkM Unggulan BLU Unila TA 2020.

\section{DAFTAR PUSTAKA}

[1] Cahyana YA. Muchordji, M. Bakrun. 2001. Pembibitan, Pembudidayaan, analisa Usaha Jamur Tiram. Penebar Swadaya. Jakarta

[2] Basuki Rahmat. 2000. Dasar-dasar Usaha Budidaya Jamur. MAJI publikasi. Bandung. 97.

[3] Departemen Kesehatan Republik Indonesia. 2005. Intoksinasi Makanan , Direktorat Jenderal Pengendalian Penyakit \& Penyehatan Lingkungan

[4] Direktorat Budidaya Tanaman Sayuran dan Biofarmaka. Jamur Tiram. Direktorat Jenderal Bina Jenderal Hortikultura. Jakarta. 23 hal

[5] Badri. Pusat Pelatihan Pertanian dan Pedesaan Swadaya (P4S) Kaliwung Kalimuncar.

[6] Winarno, F. G. 2002. Kimia Pangan dan Gizi. Gramedia Pustaka Utama. Jakarta. 